\title{
CHAPTER 57
}

\section{COMPUTATION OF ALONGSHORE ENERGY}

AND LITTORAL TRANSPORT

\author{
Theodor R Mogel 1 \\ Robert L Street, ${ }^{1}$ M ASCE \\ Byrne Perry
}

\section{ABSTRACT}

This work encompasses a study of the littoral regime of a section of the coastline of the city and county of San Francisco, California The study included a complete refraction analyses of all applicable deep water wave directıons and perıods, the determınatıon of breaker locatıons, and a computation of alongshore energy and potential littoral transport for seven stations located Just offshore along the thirty foot depth contour The waves are refracted from deep water locations to the shorel Ine us Ing the Stanford Wave Refraction computer program Wave breaking is assumed to take place whenever the computed wave height exceeds 078 times the local water depth The effect of limiting the refraction coefficient is explored since the refraction theory, in analogy with its parent theory of geometric optics, falls along caustic curves and predicts unreasonably large values for the refraction coefficient

\section{INTRODUCTION}

The proper design of coastal structures, improvements or controls depends crucially upon an accurate estimate of the amounts of sand supplied to or lost from the shore region The most significant portion of the sand supply is the littoral drift--the material of the beach and nearshore bottom moved by the action of waves and currents The rate and direction of littoral transport or the movement of littoral drift is dependent on many factors, among which are the alongshore components of water-wave energy, currents, avaılability of littoral drift, its size characteristics, shapes and mineral compositions, $t$ Ide range, and beach slope Unfortunately, neither the precıse mechanism of transport nor the interaction of the various factors is clearly understood $(1-5)$ The present work is based on the concepts that the principal supply of energy for the movement of littoral drift comes from water waves Impinging upon the shore and that an emp Irıcal relationship $(1,4)$ between transport and alongshore energy is the most appropriate means for est ımatıng the potential littoral transport

lDepartment of Civil Engineering, Stanford Universıty, Stanford, Calıfornia 94305 


\section{The Purpose and Scope of the Study}

This paper reports on a study (6) of the 1 ittoral regime of a section of the coastline of the City and County of San Francisco, Calıfornia, from the Golden Gate Bridge to Mussel Rock, south of the southerly boundary of the City and County of San Francisco The original study includes a complete refraction analysis of all applicable deep-water wave directions and perıods, determination of the locatıons of wave breaking, application of 12 monthly tables and an annual table of digitized deep-water wave characteristics (7), calculation of alongshore energy and potential littoral transport, and tabulation of shallow-water wave direction and refraction coefficients for the San Francisco coastline Here we review the original results and explore the effect of limiting the maximum value that the refraction coefficient can attaın $(8,11)$

\section{The Plan of the Study}

The basıc Inputs to the study were the hindcast deep-water wave statıstics (7) compiled for a deep-water station (number 3, Ref 7) almost due West from San Francisco By use of a computer program that carried out a refraction analysıs of waves of all applicable periods, heights and directions represented in the wave statistics tables, the deep-water values were carried to seven points distributed in shallow water along the San Francisco shoreline ( $f$ Ig 1) Then a second computer program computed the alongshore energy components of the waves and, utilizing an empirical relation between these energy components and 1 ittoral transport $(1,4)$, computed the monthly and annual potential transport at the seven points on the shoreline All computations were carried out and plots and printed tables were generated by an IBM 360, Model 67 digital computer with an associated CALCOMP 750 plotter All programs were written in FORTRAN IV

The Refraction Program solves the refraction equation and the wave intensity equation along each individual wave ray for arbitrary bottom shapes The theoretical bases for the computer program were given in detail by Dobson (g) and are discussed briefly below (cf, Ref 10) The bottom hydrographic data in digitızed form and contoured grid maps for two study areas were supplied by the San Francisco Engineer District of the $U S$ Army Corps of EngIneers The INNER GRID or study area covered the Immediate vicinity of the San Francisco shorelune from Pirates Cove, north of the Golden Gate, to south of Mussel Rock at the southern boundary of the County with a 215 unit by 150 unit grid ( 33333 feet per grid unit) The OUTER GRID or study area covered the coast from shore to approximately the 300 fathom contour and approximately from the mouth of the Russian RIver in Sonoma County to the City of Santa Cruz in Santa Cruz County with a 303 unit by 199 unit grid (1666.67 feet per grid unit) of much greater sIze The INNER GRID provided the detalled bottom contours needed for an accurate prediction of wave behavior in shallow water near the coast, while the OUTER GRID provided the link to the deep-water wave conditions Figures la and Ib show CALCOMP (computer) contour plots of the hydrography described by the grids of depths waves ranging in period from 4 to 20 seconds and in height from 1 to 25 feet and 
comıng from directions between North and South-Southeast were considered

The Drıft Program utılızes a l ınear relatıon between alongshore energy components and potential littoral transport The alongshore energy components are calculated from output supplied by the Refract Ion Program and the deep-water wave statıstıcs

\section{METHOD OF COMPUTATION}

\section{I Refraction}

\section{Theory and Background}

The theoretical basis of the present refraction computations is well known (10-12) and will only be touched on here In effect the same theory is commonly employed in hand computations and only the implementation for the computer led to differences in detall The original version of the theory comes from the physical science of geometrical optics, the key result of which is Snell's law A detailed discussion of the method was given by Dobson (g)

The main feature that has been added for the computer work is a technique for falring a smooth surface through the known bottom depth data $A$ quadratic surface is constructed to give the best fit in the sense of least squares to the local point and its surrounding neighbors Thus, the bottom is always represented as a smoothly-varyıng surface Starting from a known point on a grid and in a given initial direction, the computer program constructs a single wave ray (or orthogonal) step-by-step across the grid. Because the fitted bottom surface is smooth, and hence differentiable, the equation of wave intensity (equivalently wave height) may be solved at each step in the ray construction process, and the relationship between initial and present wave height carried forward cont inuously along a single ray This is an essential feature of the analysis without which the breaking height location computations, described below, would not have been feasible The refraction technique has proved very sat Isfactory in many test cases, as shown by comparison with exact theory and hand computations (g) Battjes (13) has recently shown that, according to both linear and nonl inear theory, the energy flux in wave propagation in three dimensions is always directed along the wave rays (orthogonals) [our wave intensity equation is based on this fact] regardless of the wave amplitude gradients and that refraction of water waves over bottoms of small slope can indeed be considered as a case of wave propagation through an inhomogeneous (depth varies), two-dimensional medium This is in agreement with the method used in the present work and current practice

The refraction theory, in analogy with its parent theory of geometric optics, falls along caustic curves and predicts unreasonably large values for the refraction coefficient $K_{r}$ near the cauştıc curve Pierson $(8,11)$ gave Just If lcation for the approximate 1 imit $K_{r}{ }^{2} \leqq 2.0$ and we have run test cases
for $K_{r}{ }^{2} \leqq 20, K_{r}{ }^{2} \leqq 40$, and $K_{r}{ }^{2}<\infty$ 


\subsection{Technique}

The refraction program constructed rays on either the OUTER GRID (303 $x$ $199 \mathrm{gr}$ id units) or the INNER GRID $(215 \times 150 \mathrm{grid}$ units) The depth data at the intersection points of the grids was provided by the San Francisco Engineer District and was digitized from their bottom hydrography charts $A$ match line for transfer of computations from one grid to the other was established

The calculation of littoral transport requires the shallow-water wave helght and direction at the point of breaking of every possible wave in the three-dimensional matrix of deep-water statistics (parameterized by deep-water height, direction and period) Accordingly, on an inward run from deep to shallow water, the refraction program punched a data card whenever breaking occurred on the INNER GRID, only those breaking points near the beach were retained For the range of wave heights and periods considered in this study, breakıng was assumed to occur whenever the height of a particular wave exceeded 078 times the local water depth. While more sophisticated criterla are avallable (12), it appears that none is significantly more accurate on the average for prototype waves in our period range Furthermore, in view of the basis of the refraction analysis on linear theory, a more refined breaking criteria does not appear warranted

The objective of the refraction analysis was to bring one ray from deep water to each of the seven target points near the shore for each applicable deep-water direction and period Because local wave height is a linear function of deep-water height, all the results for the heights between 2 and 24 feet were obtained from a single ray computation. In view of the complex hydrography of the San Francisco shore region, it was decided to work outward from each target station with fans of rays, the rays in each fan having a different period New fans were generated unt 11 a set of results were obta Ined in deep water that would permit us to run a complete set of applicable waves in from deep water (corresponding to the wave statistics) it was not possible to generate the necessary data on an outgoing run because the refraction coefficient calculation is not valid for rays started in shallow water (the starting condition of parallel rays is not correct there) Therefore, it remains necessary to retrace outgoing rays from deep water Inward In some cases it was possible to begin with incoming rays of specific period and direction and to hit a target station by using trial-and-error and the information known about adjacent stations

A study of the hindcast data (7) shows that the wave statistics are given for 22 5-degree direction segments, two-second period intervals and two-foot height intervals We used the mid-direction, mid-period and mid-heights in our refraction calculations In light of the difficulty of hitting a given direction with an outward running ray or a given station with an inward ray we established tolerance criteria of 5 degrees on direction when running outward and an $x$-distance tolerance of \pm 4 grid units when running in Tests of the results showed that no large changes in wave characteristics occurred within these tolerances In any case the major 1 ty of the runs are well within the tolerance limits which seem reasonable in view of the expected accuracy of the hindcast deep-water statistics 


\section{Notes on Computer Programmıng}

The results of the present study were obtained on an IBM 360/67 digital computer and an off-l Ine CALCOMP 750 plotter The program is an extension of the Stanford Refraction Program originally developed for the IBM 7090 Dobson (g) has given a very thorough documentation including flow charts for the main program and subrout ines in the original program, except for the CALCOMP subrout Ine calls which are highly installation dependent

The primary changes made in the or Iginal Stanford Program have been related either to differences between the IBM 7090 and IBM 360/67 computers or Improvements in the graphical displays and printed or punched outputs of the program

For the present study the program has been specifically modified to do the following

a Read the Depth data and associated fixed grid and ray constants and ident If Iers from Disc storage in the machine

b Plot wave rays on a map ( $F ı g$ 1) The map Includes labeled $X$ and $Y$ axes, a north direction arrow, sultable contours (stored on Disc also), and Identification block giving relevant parameters and Identification The contours on the INNER GRID are the shoreline and 30-foot contours, while only the shoreline is shown on the OUTER GRID If the ray is to cont Inue to another grid, the map also shows the match line outline of the next grid

c Create a punched card data deck to cont inue wave rays on another grid The $X$ - and $Y$-coordinates in the data deck have been converted to the new coordinate system The data deck is complete with all necessary title and end-of-set cards so that it may be loaded for the next run without further processing

d Create a punched-card data deck givıng coordınates and wave parameters at the 30-foot contour for each wave ray

e Create a punched-card data deck with one card for each deep-water wave height on each ray when the wave breaks $(\mathrm{H} / \mathrm{D}>078)$ for helghts of 2 to 24 feet in increments of 2 feet These cards contained, in addition to the wave height, direction, period and spacial location, the shoaling coefficient, the deep-water height, the water depth and the local angle between the wave ray and the gradient of the bottom topography

f Limit the refraction coefficient to a specific value

Figures la and $1 \mathrm{~b}$ show sample plotter output from the refraction program A ray was started a short distance to each side of each of the actual rays used to better Illustrate the shift Ing of the wave front Tables la and lb are the printouts generated for one of the rays shown in the figures 


\section{Littoral Transport}

\section{Analysis and Hindcast Data}

Nat Ional Marine Consultants compiled deep-water wave statistics based upon meteorological records and charts for the years 1956, 1957 and 1958 for seven deep-water stations along the California coast (7) The wave hindcast data for deep-water sea (generated by local wind) and swell were given as height-period-direction average frequency distributions in percent monthly and annualiy A digitized data deck for Station 3 (Lat Itude 376 degrees $N$, Longitude 1235 degrees $W$ ) was provided the authors by the San Francisco Engineer District This station is due west of San Francisco As none of the other stations were close to this area, Station 3 was the only data source, cf, Fairchild (3) who interpolated between several stations for an east-coast study

The treatment of deep-water wave statistics and littoral transport calculations was based on the methods of Saville (14) and Fairchild (3) In particular, sea and swell energies were added linearly, and the significant wave heights, corrected in accordance with Falrchild (3) and Saville (14), were used to est imate the wave energy at the shore The refraction analysis used the dominant wave perıod, as outlined by Saville (14), associated with the significant wave heights given in the statistical data

Littoral transport was computed from the alongshore energy components derived from the combination of wave statistics and refract ion program output for the seven shallow-water stations shown in Fig lb An empirical littoral transport equation was obtained from Fig 2-22 of CERC Technical Report No 4 (1) According to this figure, the potential littoral transport past a point on shore and caused by a given period wave of given deepwater height and direction is

$$
Q=128 E_{a} \quad 10^{-6} \mathrm{cu} \quad \mathrm{yds} / \text { month }
$$

where

$$
\begin{aligned}
& E_{a}^{l-}=058 E_{a} F_{1 j} k_{l}, \\
& E_{a}=5400 \frac{\gamma H_{b}^{2} L_{o}}{T K_{S}^{2}} \sin \alpha_{c} \cos \alpha_{c}=177 \quad 10^{6} \frac{H_{b}^{2}}{K_{S}^{2}} \sin \alpha_{c} \cos \alpha_{c} \\
& \text { in } \mathrm{ft} \text {-lbs/ft of beach/day, } \\
& \alpha_{c}=\text { angle between wave ray and the gradient of the bottom } \\
& \text { hydrography in degrees, } \\
& \gamma=\text { specific we Ight of sea-water }=64 \mathrm{lbs} / \mathrm{ft}^{3} \text {, }
\end{aligned}
$$




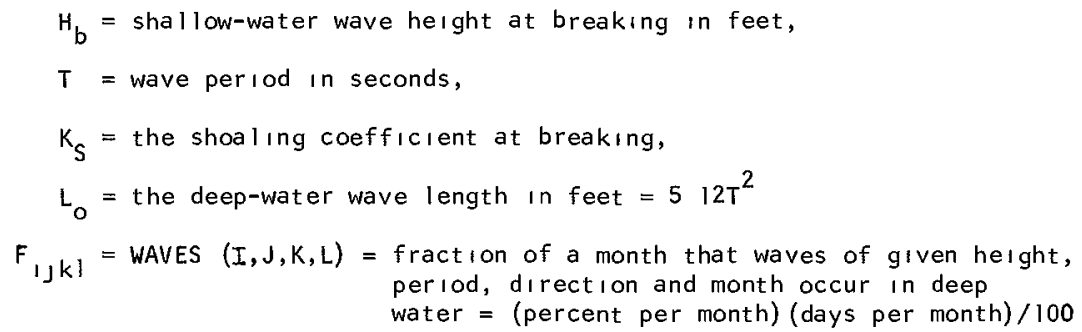

The actual (as opposed to potential) littoral transport may be less than $Q$ If bottom bed material is not avallable at the point in question The factor 058 is required (14) to reduce the given deep-water spectral energy for significant waves to the proper average energy that causes littoral transport Note that in this analysis the littoral transport caused by waves of varyıng helghts will occur where the wave breaks, thus, for each station location our transport results reflect the alongshore transport on the average through the broad-band breaking or surf zone (see Fig L) created by a set of deep-water waves whose common point is that they all pass through (or near) a given station location ( 1 through 7) on the 30-foot contour along the San Francisco shorel ine

The machine calculations were checked by hand for those cases in which only one deep-water wave height for a given period and direction had a nonzero occurrence in a month or for the year

\section{Programming and Output}

The operation of the program that calculates the alongshore energy and potential littoral transport is particularly simple and proceeds as follows

a The program reads the digitized sea data (Table 3 , Ref 7) and constructs WAVES $(I, J, K, L)$ for the sea data for each month

b The program reads the swell data and adds it to the appropriate WAVES $(I, J, K, L)$

c The program reads a refractıon-program-punched input card for a particular deep-water height, direction, perıod and station (always starting with the 24-foot he Ight and working downward) and constructs $\mathrm{E}_{\mathrm{a}}{ }^{\prime \prime}$ for that card Cards are read and energies calculated unt 1 all the heights for a given ray are surveyed, and their energies are added together to find the total energy for that period and direction only the last complete height survey (24 feet to 2 feet) is used to calculate the transport, $1 \mathrm{e}$, only the breakıng zone cont Iguous to the beach is considered to cause transport No allowance has been made for energy losses in prior breakıng zones away from the beach (see Sec 4 2)

d The program repeats $c$ for the remaınıng perıods and directions 
e The littoral transports $Q$ corresponding to the $E_{a}^{-}$for each period and direction are computed

$f$ Tables of $\mathbf{E}_{a}^{-}$and $Q$ are constructed for each station

\section{RESULTS AND DISCUSSION}

\section{Transport and Energy Tables}

The tables of littoral transport and alongshore energy components computed by the Drift Program for the three limits on $K_{r}$ are given in Tables 2 and 3 for each of the seven stations of the study Results are given for each month in the year and the annual total transport as a station $A$ positive sign indicates energy components and transport motion up-coast or generally North

As noted above (Secs 213 and 221 ) the alongshore energy component computation is based upon the local angle $\alpha$ at breaking between the wave ray and the gradient of the bottom hydrography (the perpendicular to the local bottom contour) We considered the use of the mean gradient direc$t$ ion of the beach as a whole near any given station in lieu of the local gradient Tests with this concept had predictable results, namely, the transport and energy components vary widely for small changes in mean beach gradient direction Because of the complex hydrography near the shore ( $F ı g \quad l b)$ and the wide zone of breaking ( $F, g 2$ ) the direction of a ray at the breaking point for a given wave is not correlated to any observable mean beach gradient direction Accordingly, no computations ut Ilızed an $\alpha$ based on mean beach gradients, rather, the ray direction was correlated with the bottom contour at the actual breaking point

As can be seen from the alongshore energy and littoral transport tables (Tables 2, 3, \&4), l Imıtıng the maxımum value of $\mathrm{K}_{r}$ tends to make the calculated energy and transport more uniform The majority of the alongshore energy at each station is the result of a few rays When some of these rays pass through or near a caustic and their $K_{r}$ is not restricted, their dominance is exaggerated and they break further from shore By limiting the maximum value that $K_{r}$ can attain, the dominance of these waves is reduced and they break closer to the beach zone Station I, for example, has a ray from the west which contributes most of the energy and transport When this ray crosses the $30 \mathrm{ft}$ contour $K_{r}=367$ When $K_{r}$ is restricted to a more reasonable value, the dominance of the ray dimınishes and the net transport is brought into line with the transport of station 3 as expected because the bottom hydrography near these two stations is simılar

\section{Unusual Features}

Several features of the bottom hydrography are worth noting The Faralion Islands are the visible portion of a shoaling region which lies mainly between 60 fathoms and the surface Long waves, in particular, are affected by this region. The peaked nature of the region causes bending of the longer waves which is quite unpredictable and led to much of the ted Ium of locating the starting positıons of these longer waves 
The Fourfathom Bar blocks or diverts much of the wave energy of the longer period waves from the Golden Gate area The small energy and transport figures for stations 6 and 7 are a direct result of this blocking effect The Southern and Central portions of the San Francisco Bar also severely bend the rays However this effect is quite predictable

\section{Comparison with other studies}

Kamel (15) made a study of sand transport along the Calıfornia Coast in the Russian River-Point San Pedro reach using, mainly, radioactıve tracer and heavy mineral concentratıons His study predicts a general transport in the southerly direction In the region between the Golden Gate and Merced Lake (our statıons 4 and 2) no predomınant direction of transport was predicted and the radioact Ive tracer samples predicted a Southern transport near our stations 1 and 3 However a close examination of the heavy mineral concentration data for the same region shows a Northern transport for the same region

Adding to the uncertainty Johnson (16) states in his study of the Half Moon Bay-Russian River region that little if any material is transported in this littoral zone our results indicate, with the exception of station 2, a northerly direction of sand transport Johnson (16) also concludes that there is no major source of littoral materlals along the Half Moon Bay-Russian River region indicating that perhaps the experimental results revealed not what is taking place now but what has taken place over geologic time

\section{Conclusions}

\section{Conclusions based on the present results}

In this study we brought together three essent lal ingredients to synthesize the potential littoral transport and alongshore energy The combination of deep-water hindcast wave statıstics, linear refract Ion of wave components and an empirical relation between energy and transport produced energy and transport patterns which clearly show that

1) The average annual transport and energy direction is north

2) The Farallon Islands and their associated shoalıng region both block wave energy from the shore and bend and focus wave rays to zones not otherwise reachable

3) Limiting the maximum value of $K_{r}$ produces energy and transport predictions which are more uniform and realistic

However it must be emphasized that the littoral transport results are obtalned from an empirical energy-transport relation developed for other coastal areas and based on very scattered data $(4,5)$ Accordingly, within the accuracy of the hindcast data and the l Inear refraction analys Is, we consider the alongshore energy distribution to be accurate, but the potential (computed) littoral transport can only be considered as a qualitative indicator of the actual transport 


\section{Recomendations for Modification of the Present Technique}

Three problem areas arise in connection with the present study First, a large effort in terms of man-hours and computer time is expended in selecting the desired wave rays for each deep-water wave direction and period that run to each station second, and more significant, no account is made of energy losses that occur through wave breaking on bars and other shoaling regions far from the beach area Third, the relationship between energy and sand movement rests on little in the way of sound principles and analysis, Thornton (5) has recently made a start in remedying this situation, but his success is limited

Battjes (13) proposes a refraction technique in which the wave characteristics are determined as cont inuous field variables over an ent ire grid This method requires the solution of a pair of non-linear partial differential equations, but would give the necessary data at all points along a shoreline However his method would require large amounts of storage $\left(\sim 10^{6}\right.$ words for our outer Grid) and long run tımes (probably more than 10 minutes per wave direction and perıod). Our present program has none of these prob lems

The greatest need, however, is to find a way to account for energy loss when a wave breaks offshore before comıng into the breaker zone Battjes (13) technique assumes no energy losses from the wave system so would suffer from some of the present inaccuracies

\section{ACKNOWLEDGEMENT}

The basic refraction and littoral drift studies were carried out under Contract No DACW07-68-C-0054 for the U $S$ Army Engineer District, San Francisco, Corps of Engıneers 


\section{REFERENCES}

1 Shore Protectıon, Plannıng and Desıgn, Tech Rep No 4 (3rd ed), U S Army Coastal Eng Ineering Research Center, Dept of the Army, Corps of Engıneers, Washıngton, D C , June 1966

$2 \mathrm{~J} \mathrm{~W}$ Johnson and $\mathrm{P} S \mathrm{~S}$ Eagleson, "Coastal Processes," Estuary and Coastlıne Hydrodynamıcs, McGraw-Hill Book Co, Inc, New York, Chapter 9,1966

3 J C Falrchlld, "Correlation of Littoral Transport with Wave Climate along Shores of New York and New Jersey," Tech Memo No 18, U S Army Coastal Engıneerıng Research Center, Dept of the Army, Corps of Engineers, Washington, D C , November 1966

4 T Saville, Jr, G M Watts," Coastal Regime, Recent U S Experience," XXII Internat Ional Navigation Congress, Parıs, 1969

5 E B Thornton, "Longshore Currents and Sedıment Transport," Tech Rep No 5, Department of Coastal and Oceanographic Engineering, University of Florida, Ga Inesville, Florıda, December, 1969

6 Street, R L, T Mogel and B Perry, "Computation of the Littoral Regime of the Shore of San Francisco County, Cal Ifornia, by Automatic Data Processing Methods," Final Report, Contract No DACW07-68-0054, $U$ S Army Engineer District, San Francisco, Corps of Engineers, I January 1969

7 "Wave Statıstics for Seven Deep Water Statıons Along the Calıforn Ia Coast," Natıonal Marıne Consultants, Santa Barbara, Calıfornı, December 1960

$8 \mathrm{~W} \mathrm{~J}$ Pierson, "The interpretation of Crossed Orthogona is in Wave Refraction Phenomena," Tech Memo No 21, Beach Erosion Board, Corps of Engıneers, January 1951

$9 \mathrm{R} S \mathrm{~S}$ Dobson, "Some Applicatıons of a Dıgıtal Computer to Hydraulıc Engıneerıng Problems," Tech Rep No 80, Dept of Civil Engineerıng, Stanford Unıversity, Stanford, Calıfornı, June 1967, DDC AD No 659309

10 G H Keulegan, J Harrison, "Tsunamı Refraction Dıagrams by Digıtal Computer," J Waterways and Harbor DIvision, Proc ASCE, V96, No WW2, Paper 7261, May 1970

11 W J Pierson, G Neumann and R W James, Practical Methods for Observing and Forecasting Ocean Waves by Means of Wave Spectra and Statıstics, U S Navy Hydrographic Office, Publication No 603, 1955 
$12 \mathrm{R} L$ Wiegel, Oceanographical Engineering, Prentice-Hall, Inc, Englewood Cliffs, New Jersey, 1964

13 J A Battjes, "Refraction of Water Waves," J Waterways and Harbor DIVIsion, Proc ASCE, V 94, No WW4, Paper 6206, November $196 \mathrm{~B}$

$14 \mathrm{~T}$ Saville, Jr, "North At lant Ic Coast Wave Stat Istıcs HIndcast by Bretschneıder-Revised Sverdrup-Munk Method," Beach Erosion Board Tech Memo No 55, Dept of the Army, Corps of Engıneers, Washington, D C , November 1954

15 A M Kamel, "Lıttoral Studies Near San Francısco Usıng Tracer Technıques," Tech Memo No 131, Beach Erosion Board, November 1962

$16 \mathrm{~J} W$ Johnson, "Nearshore Sedıment Movement--Central Calıfornı Coast," Coastal Engıneering, ASCE Santa Barbara Specialty Conference, Chapter 23, 0ct ober 1965 

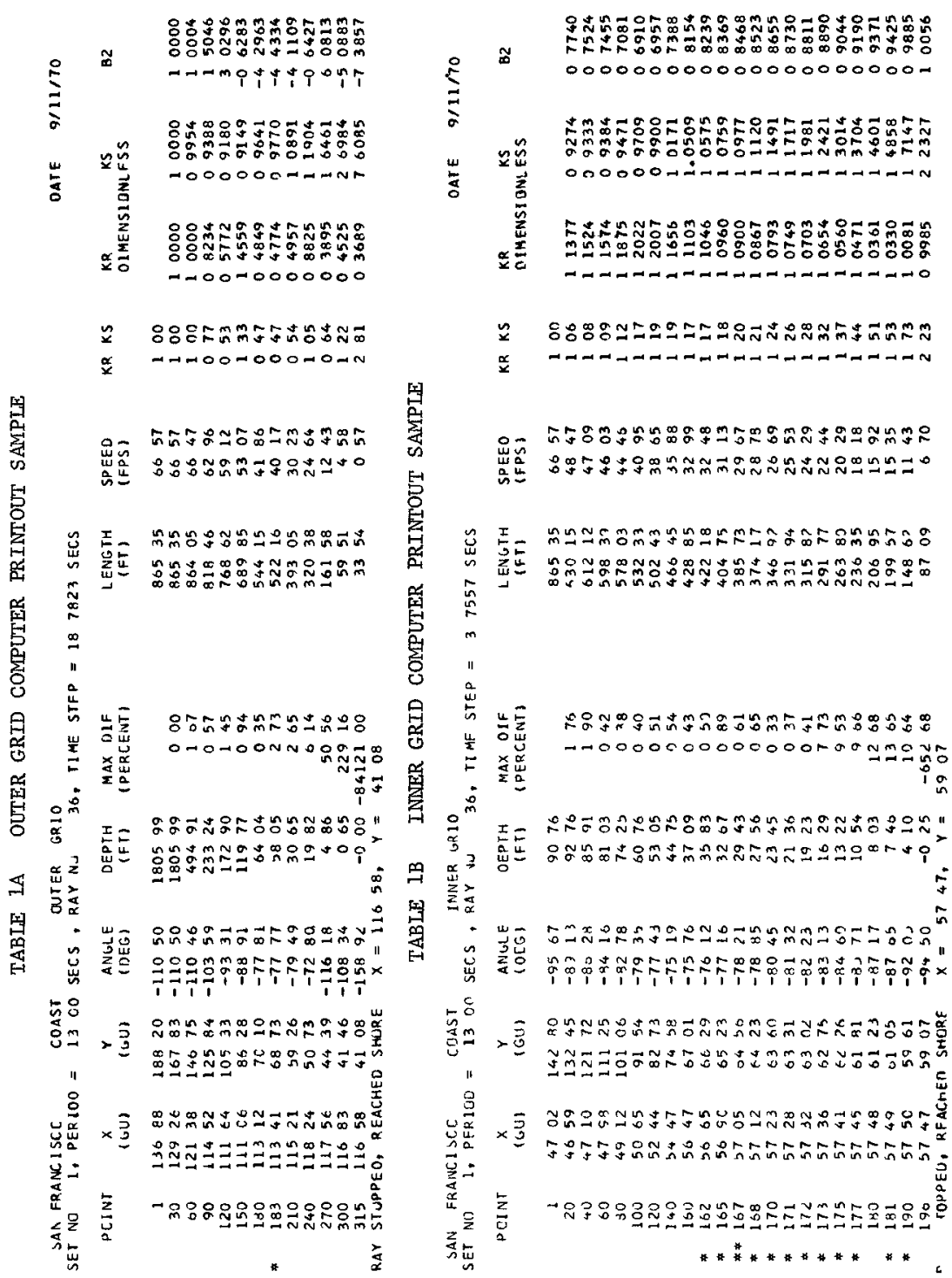
TA8LE 2 ALONGSHORE ENERGY FOR $K_{r}<\infty\left(10^{6} \mathrm{ft}-1 \mathrm{bs} / \mathrm{ft}\right.$ of beach)

$\begin{array}{lrrrrrrr}\text { STAT ION } & 1 & 3 & 2 & 5 & 4 & 6 & 7 \\ \text { JAN } & 3489 & 1452 & 4180 & 22092 & 5031 & 666 & 225 \\ \text { FE8 } & 4625 & 3114 & 8302 & 21418 & 8030 & 244 & 1084 \\ \text { MAR } & 2167 & 1180 & 2705 & 10584 & 2583 & -9 & 4 \\ \text { APR } & 769 & 824 & -39 & 5195 & 2642 & 2617 & 177 \\ \text { MAY } & 104 & 347 & -261 & 1253 & 1271 & -143 & 169 \\ \text { JUN } & -429 & -80 & -247 & -1717 & 75 & -3 & 1 \\ \text { JUL } & -361 & -56 & -90 & -1163 & 34 & -5 & 2 \\ \text { AUG } & -411 & -45 & -182 & -1043 & 35 & 23 & 2 \\ \text { SEP } & -92 & 110 & 152 & -27 & 349 & -20 & 7 \\ \text { OCT } & 305 & 226 & 297 & 1206 & 1049 & 384 & 70 \\ \text { NOV } & 982 & 89 & 88 & 2669 & 839 & 1081 & -5 \\ \text { DEC } & 1866 & 603 & 1009 & 5857 & 1430 & 1171 & -14 \\ \text { TOTAL } & 13014 & 7764 & 15914 & 66324 & 23368 & 6006 & 1722\end{array}$

POTENTIAL LITTORAL TRANSPORT FOR $K_{r}<\infty\left(10^{3}\right.$ cubIC yards)

$\begin{array}{lrrrrrrr}\text { STATION } & 1 & 3 & 2 & 5 & 4 & 6 & 7 \\ \text { JAN } & 447 & 186 & 535 & 2828 & 644 & 86 & 29 \\ \text { FE8 } & 592 & 399 & 1063 & 2741 & 1027 & 31 & 139 \\ \text { MAR } & 277 & 151 & 346 & 1355 & 331 & -1 & 1 \\ \text { APR } & 98 & 105 & -5 & 665 & 338 & 335 & 23 \\ \text { MAY } & 13 & 44 & -33 & 160 & 163 & -18 & 22 \\ \text { JUN } & -55 & -10 & -32 & -220 & 10 & 0 & 0 \\ \text { JUL } & -46 & -7 & -12 & -149 & 4 & 1 & 0 \\ \text { AUG } & -53 & -6 & -23 & -134 & 4 & 3 & 0 \\ \text { SEP } & -12 & 14 & 20 & -4 & 45 & -3 & 1 \\ \text { OCT } & 39 & 29 & 38 & 154 & 134 & 49 & 9 \\ \text { NOV } & 126 & 11 & 11 & 342 & 107 & 138 & -1 \\ \text { DEC } & 239 & 77 & 129 & 750 & 183 & 150 & -2 \\ \text { TOTAL } & 1665 & 993 & 2037 & 8488 & 2990 & 770 & 221\end{array}$


TABLE 3 ALONGSHORE ENERGY FOR $k_{r} \leqq 2\left(10^{6} \mathrm{ft}-1 \mathrm{bs} / \mathrm{ft}\right.$ of beach)

$\begin{array}{lrrrrrrr}\text { STAT ION } & 1 & 3 & 2 & 5 & 4 & 6 & 7 \\ \text { JAN } & 3029 & 1440 & -184 & 6701 & 3708 & 21 & 225 \\ \text { FE8 } & 3719 & 3006 & 199 & 7888 & 6822 & 319 & 1084 \\ \text { MAR } & 1410 & 1097 & -616 & 1963 & 1564 & 35 & 4 \\ \text { APR } & 392 & 789 & 156 & 1420 & 2001 & 579 & 177 \\ \text { MAY } & -196 & 342 & -185 & -806 & 462 & 12 & 169 \\ \text { JUN } & -556 & -80 & -198 & -1722 & 75 & 37 & 1 \\ \text { JUL } & -435 & -56 & -67 & -1162 & 34 & 9 & 2 \\ \text { AUG } & -469 & -45 & -182 & -1044 & 35 & 37 & 2 \\ \text { SEP } & -251 & 107 & -192 & -496 & 166 & 30 & 7 \\ \text { OCT } & 13 & 211 & -594 & -49 & 458 & -18 & 70 \\ \text { NOV } & 179 & 89 & -644 & -304 & 330 & -49 & -5 \\ \text { OEC } & 943 & 562 & -1673 & 925 & 881 & -28 & -14 \\ \text { TOTAL } & 7778 & 7462 & -4179 & 13314 & 16536 & 984 & 1722\end{array}$

POTENT IAL LITTORAL TRANSPORT FOR $K_{r} \leqq 2\left(10^{3}\right.$ cubIC yards)

$\begin{array}{lrrrrrrr}\text { STAT ION } & 1 & 3 & 2 & 5 & 4 & 6 & 7 \\ \text { JAN } & 388 & 184 & -24 & 858 & 475 & 3 & 29 \\ \text { FEB } & 476 & 385 & 26 & 1010 & 873 & 41 & 139 \\ \text { MAR } & 180 & 140 & -79 & 251 & 200 & 4 & 1 \\ \text { APR } & 50 & 101 & 20 & 182 & 256 & 74 & 23 \\ \text { MAY } & -25 & 44 & -24 & -103 & 59 & 2 & 22 \\ \text { JUN } & -71 & -10 & -25 & -221 & 10 & 5 & 0 \\ \text { JUL } & -56 & -7 & -9 & -149 & 4 & 1 & 0 \\ \text { AUG } & -60 & -6 & -23 & -134 & 4 & 5 & 0 \\ \text { SEP } & -32 & 14 & -25 & -63 & 21 & 4 & 1 \\ \text { OCT } & 2 & 27 & -76 & -6 & 59 & -2 & 9 \\ \text { NOV } & 23 & 11 & -82 & -39 & 42 & -6 & -1 \\ \text { OEC } & 121 & 72 & -214 & 118 & 113 & -4 & -2 \\ \text { TOTAL } & 996 & 955 & -535 & 1704 & 2116 & 127 & 221\end{array}$


TABLE 4 ALONG5HORE ENERGY FOR $k_{r} \leqq 141\left(10^{6} \mathrm{ft}-1 \mathrm{bs} / \mathrm{ft}\right.$ of beach)

\begin{tabular}{lrrrrrrr} 
5TATION & 1 & 3 & 2 & 5 & 4 & 6 & \multicolumn{1}{c}{7} \\
JAN & 3200 & 1357 & 6 & 3233 & 2921 & 168 & 128 \\
FEB & 3130 & 2537 & 1477 & 5295 & 4478 & 346 & 625 \\
MAR & 902 & 792 & -496 & 882 & 1229 & 83 & -9 \\
APR & 260 & 583 & -243 & -13 & 1426 & 60 & 101 \\
MAY & -342 & 295 & -171 & -961 & 294 & 61 & 92 \\
JUN & -593 & -80 & -190 & -1712 & 75 & 53 & 1 \\
JUL & -456 & -56 & -63 & -1160 & 34 & 15 & 2 \\
AUG & -486 & -45 & -182 & -1041 & 35 & 45 & 2 \\
SEP & -327 & 67 & -159 & -499 & 133 & 60 & 4 \\
OCT & -237 & 163 & -446 & -334 & 353 & 64 & 34 \\
NOV & -179 & 89 & -578 & -468 & 273 & 62 & -8 \\
DEC & 642 & 434 & -1902 & 228 & 739 & 133 & -19 \\
TOTAL & 5514 & 6136 & -2947 & 3450 & 11990 & 1150 & 953
\end{tabular}

POTENTIAL LITTORAL TRAN5PORT FOR $K_{r} \leqq 141$ (10 $0^{3}$ cubIC yards)

$\begin{array}{lrrrrrrr}\text { STATION } & 1 & 3 & 2 & 5 & 4 & 6 & 7 \\ \text { JAN } & 410 & 174 & 1 & 414 & 374 & 22 & 16 \\ \text { FEB } & 401 & 325 & 189 & 678 & 573 & 44 & 80 \\ \text { MAR } & 115 & 101 & -64 & 113 & 157 & 11 & -1 \\ \text { APR } & 33 & 75 & -31 & -2 & 183 & 8 & 13 \\ \text { MAY } & -44 & 38 & -22 & -123 & 38 & 8 & 12 \\ \text { JUN } & -76 & -10 & -24 & -219 & 10 & 7 & 0 \\ \text { JUL } & -58 & -7 & -8 & -149 & 4 & 2 & 0 \\ \text { AUG } & -62 & -6 & -23 & -133 & 4 & 6 & 0 \\ \text { SEP } & -42 & 9 & -20 & -64 & 17 & 8 & 1 \\ \text { OCT } & -30 & 21 & -57 & -43 & 45 & 8 & 4 \\ \text { NOV } & -23 & 11 & -74 & -60 & 35 & 8 & -1 \\ \text { DEC } & 82 & 56 & -243 & 29 & 95 & 17 & -2 \\ \text { TOTAL } & 706 & 787 & -376 & 441 & 1535 & 149 & 122\end{array}$




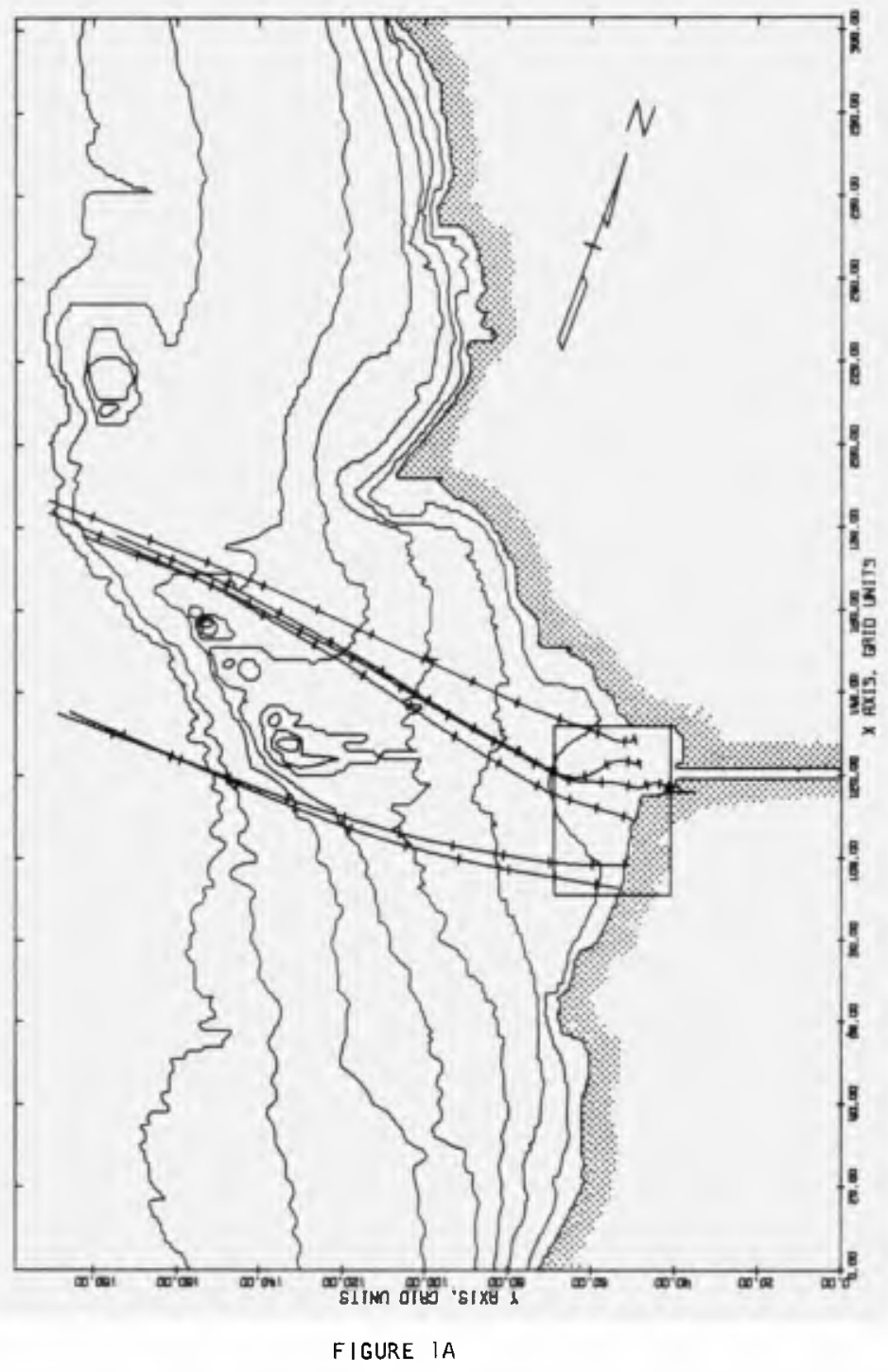

OUTER GRID CONTOUR MAP and

13 SEC. WAVE RAYS TO STAT IONS $1,2,3,4,5,7$ 


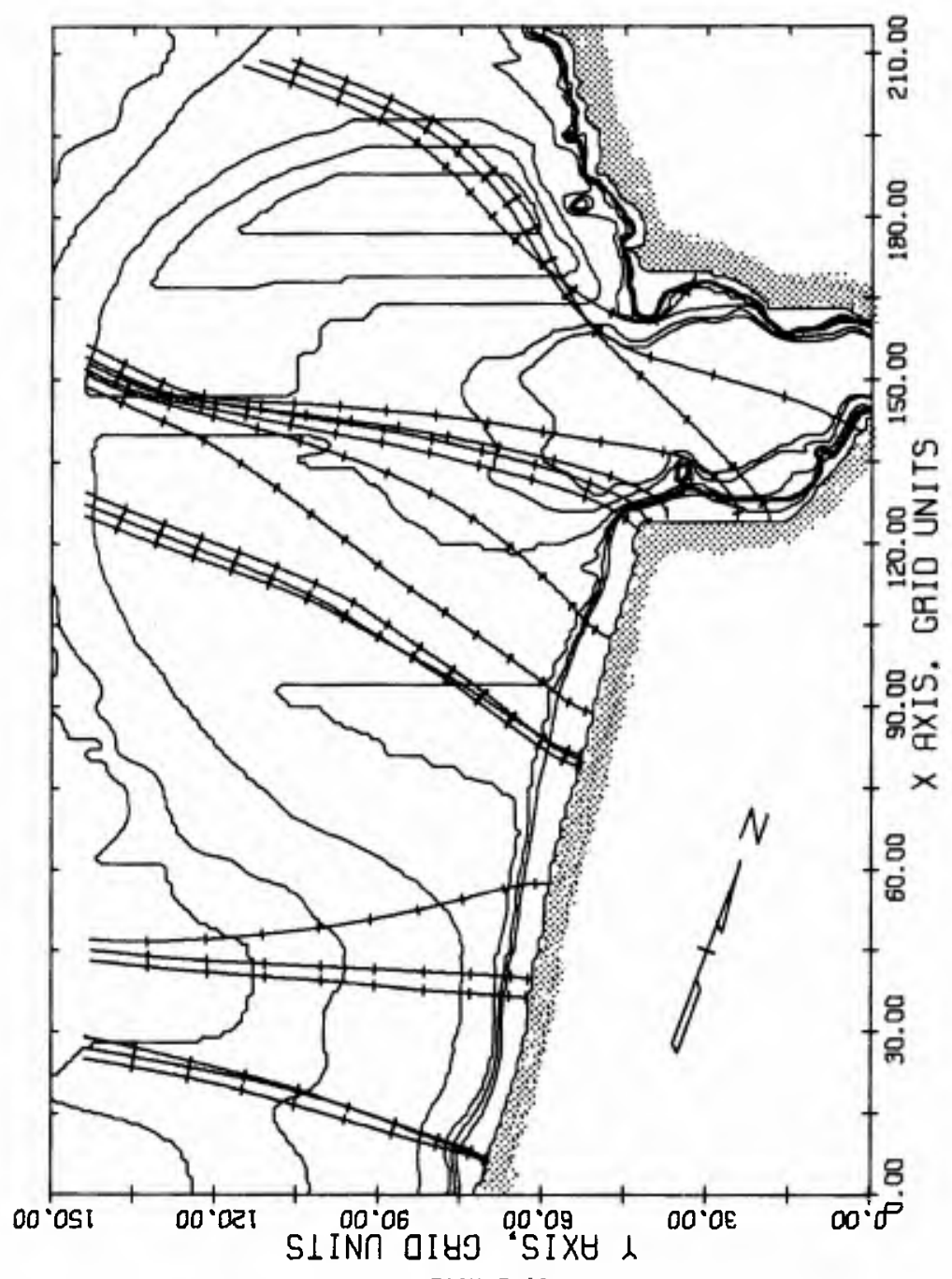

FIGURE IB

INNER GRID CONTOUR MAP and

13 SEC. WAVE RAYS TO STATIONS $1,2,3,4,5,7$ 


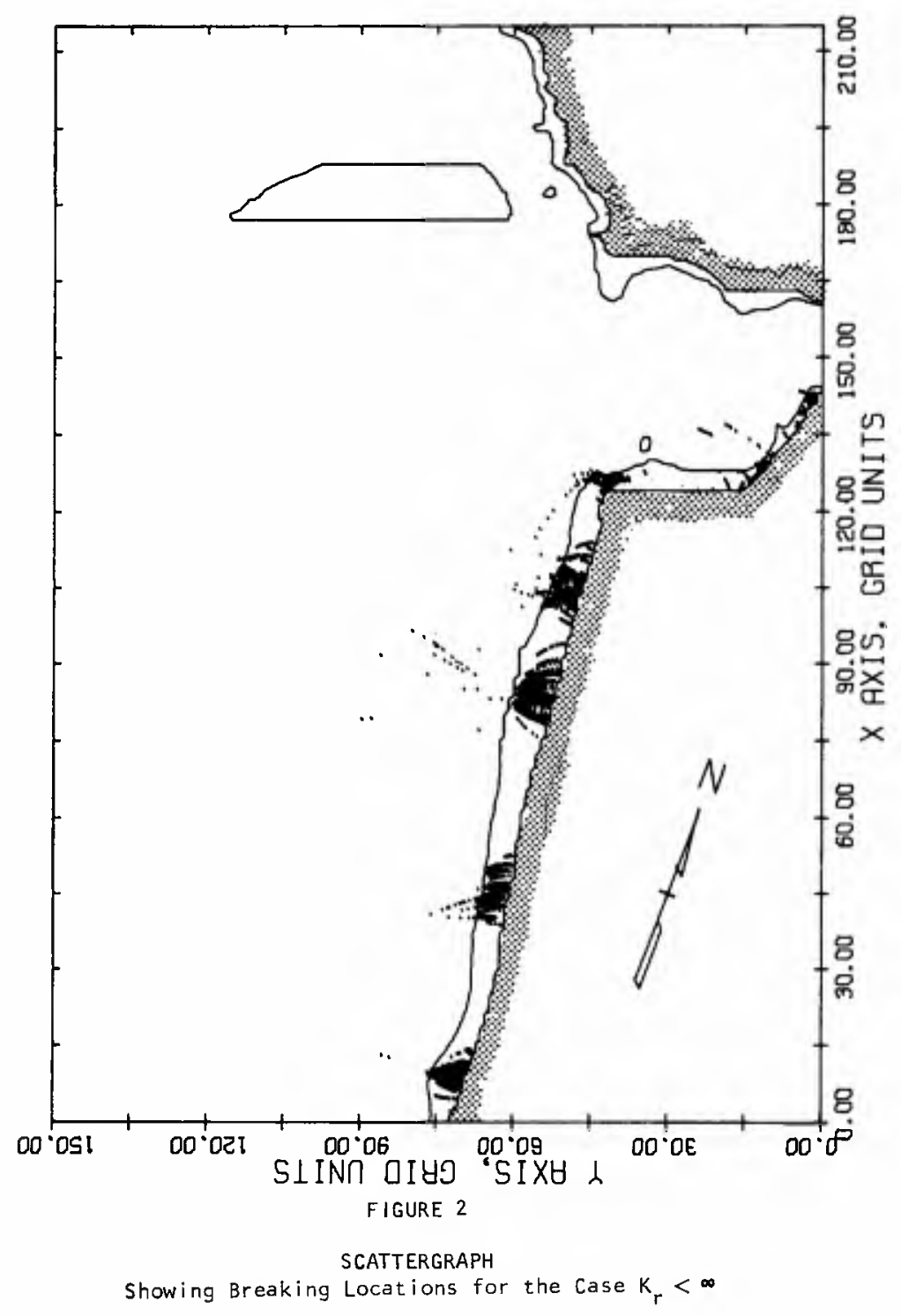


